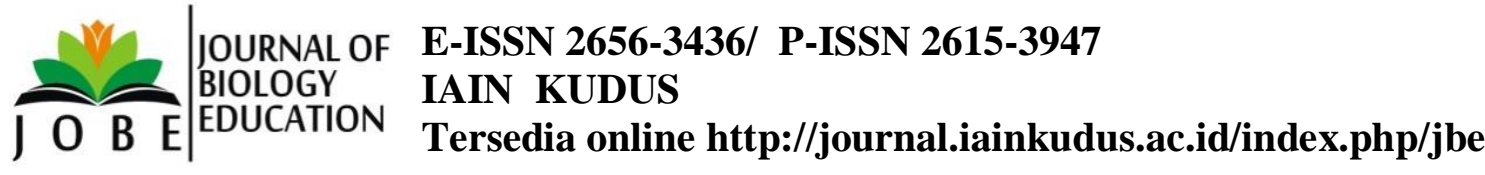

\section{Biodiversitas Capung Subordo Anisoptera di Sekitar Aliran Sungai Muria Desa Colo Kudus}

\author{
Ellatur Rokhmah ${ }^{1}$, Siti Mukhlishoh Setyawati ${ }^{2}$, Saifullah Hidayat $^{3}$ \\ Universitas Islam Negeri Walisongo Semarang \\ ellaturrokhmah@gmail.com, hidayatsaifullah@walisongo.ac.id, \\ siti.mukhlishoh@walisongo.ac.id
}

\begin{abstract}
ABSTRAK
Perairan yang memiliki kualitas air bersih sangat mempengaruhi keragaman jenis capung. Penelitian ini bertujuan untuk menghitung indeks keanekaragaman, indeks kemerataan, dominansi dan FBI (Family Biotic Indeks) capung Anisoptera dan untuk membandingkan kualitas air pada tiga area yang berbeda terhadap keanekaragaman jenis capung Anisoptera di sekitar aliran sungai gunung Muria Desa Colo Kudus Jawa Tengah. Penelitian ini menggunakan pendekatan kualitatif dengan metode deskriptif. Hasil dari penelitian tersebut ditemukan lima spesies capung pada tiga area penelitian. Hasil analisis indeks keanekaragaman bahwa area $1(0,99)$ dan area $3(0,97)$ tergolong rendah, sedangkan area $2(1,12)$ tergolong sedang. Analisis indeks kemerataan menunjukkan bahwa area $1(0,71)$ dan area $2(0,62)$ cukup merata, sedangkan area 3 $(0,88)$ hampir merata. Hasil analisis indeks dominansi menunjukkan bahwa area 1 $(0,42)$ dan area $2(0,37)$ tergolong sedang, sedangkan area $3(0,20)$ rendah. Hasil analisis FBI (Family Biotic Indeks) menunjukkan bahwa ketiga area tersebut memiliki kualitas air paling baik atau tidak tercemar bahan organik. Perbandingan kualitas air pada ketiga area terhadap keanekaragaman jenis capung Anisoptera yaitu area 1 dan area 3 memiliki kualitas air bersih akan tetapi memiliki keanekaragaman jenis capung Anisoptera rendah, sedangkan untuk area 2 memiliki kualitas air tercemar akan tetapi memiliki keanekaragaman jenis capung Anisoptera sedang.
\end{abstract}

Kata kunci : Biodiversitas, Capung Anisoptera, Kualitas air

\section{ABSTRACT}

The rivers that have clean water quality affect the diversity of dragonflies. This study aims to calculate the diversity index, evenness index, dominance and FBI (Family Biotic Index) of Anisoptera dragonflies and to compare water quality in three different areas to the diversity of Anisoptera dragonfly species around the Muria mountain streams in Colo Kudus Village, Central Java. This research uses a qualitative approach with descriptive methods. The results of the study found five species of dragonflies in the three study areas. The diversity index analysis results that area 1 (0.99) and area 3 (0.97) are classified as low, while area 2 (1.12) is classified as moderate. Evenness index analysis shows that area 1 (0.71) and area 2 (0.62) are fairly evenly distributed, while area $3(0.88)$ is almost evenly distributed. The results of the analysis of the dominance index indicate that area 1 (0.42) and area $2(0.37)$ are classified as moderate, while area $3(0.20)$ is low. The results of the FBI (Family Biotic Index) 
analysis show that the three areas have the best water quality or are not polluted by organic matter. Comparison of water quality in the three areas with the diversity of Anisoptera dragonflies, area 1 and area 3 has clean water quality but has a low Anisoptera dragonfly species diversity, while for area 2 has polluted water quality but has a diversity of medium Anisoptera dragonflies

Keywords: Biodiversity, Anisoptera Dragonflies, Water quality

\section{PENDAHULUAN}

Indonesia merupakan negara yang memiliki keanekaragaman hayati melimpah, dengan keanekaragaman hayati yang melimpah tersebut Indonesia mendapat julukan negara megabiodiversitas (Mushoffa, 2017). Serangga merupakan salah satu keanekaragaman hayati di Indonesia yang memiliki jumlah setengah dari populasi spesies hewan di dunia. Salah satu jenis serangga yang banyak terdapat di Indonesia yaitu capung (Setyawati dkk., 2015). Capung merupakan salah satu serangga yang memiliki penyebaran cukup luas diantaranya yaitu sawah, kebun, danau, sungai, dan hutan (Rizal dan Hadi, 2015). Secara umum capung dapat ditemui di beberapa habitat mulai dataran rendah hingga dataran tinggi. Faktor yang terpenting dalam kehidupan capung yaitu habitat yang memiliki perairan atau dekat dengan perairan karena hal tersebut sangat berpengaruh pada siklus hidup capung. Kondisi perairan juga sangat berpengaruh terhadap keragaman jenis capung. Jenis ragam capung dapat ditemui pada perairan yang memiliki kualitas air yang belum tercemar (Baskoro, 2018).

Capung dibagi menjadi dua subordo yaitu subordo Anisoptera (capung biasa) dan subordo Zygoptera (capung jarum), capung Anisoptera sayap belakang lebih lebar dibandingkan sayap depan (Herpina dkk., 2014). Capung Anisoptera memiliki ukuran tubuh lebih gemuk dan capung tersebut dikenal memiliki kemampuan terbang dengan cepat (Hanum dkk,. 2013). Capung dapat dijadikan sebagai bioindikator air bersih, dimana capung tersebut dapat digunakan untuk memantau kualitas air disekitar habitat capung. Capung memiliki peranan penting terhadap kehidupan manusia. Di negara Asia Timur capung dimanfaatkan sebagai biota pengusir penyakit malaria atau demam berdarah, karena nimfa capung dapat memangsa jentik-jentik nyamuk yang dapat menyebabkan penyakit malaria. Capung juga dapat dijadikan sebagai bioindikator air bersih, karena nimfa capung tidak dapat hidup pada perairan yang memiliki kualitas air yang kurang bersih atau tercemar serta nimfa capung juga tidak dapat hidup pada perairan yang tidak memiliki tumbuhan (Susanti dkk., 1998). 
Gunung Muria merupakan salah satu gunung di Jawa Tengah yang memiliki potensi keberadaan capung dan perairan. Menurut penelusuran peneliti menunjukkan bahwa belum adanya database tentang keanekaragaman capung dan kualitas air di perairan gunung Muria terutama di sekitar desa Colo, hal tersebut dikarenakan bahwa belum adanya penelitian yang mengkaji tentang keanekaragaman capung dan kualitas air di kawasan tersebut. Hasil pra riset menunjukkan bahwa terdapat beberapa capung yang ditemukan di kawasan gunung Muria terutama yang dekat dengan perairan. Capung yang ditmeukan pada saat pra riset yaitu Orthetrum sabina dan Trithermis festiva. Hal tersebut tidak menutup kemungkinan apabila dilakukan penelitian lebih lanjut mengenai biodiversitas capung dan kualitas air di kawasan gunung Muria terutama desa Colo Kudus Jawa Tengah

Tujuan penelitian ini yaitu untuk menghitung indeks keanekaragaman, indeks kemerataan, indeks dominansi, dan FBI (Family Biotic Indeks) serta untuk membandingkan kualitas air pada ketiga area penelitian terhadap keanekaragaman jenis capung di aliran sungai sekitar gunung Muria desa Colo Kudus Jawa Tengah.

\section{METODE PENELITIAN}

Jenis penelitian ini yaitu penelitian lapangan. Data penelitian ini diperoleh dari lapangan dan peneliti turun langsung ke lapangan untuk mendapatkan data penelitian tersebut (Raco, 2010). Penelitian ini menggunakan pendekatan kuantitatif dengan metode deskriptif. Penelitian tersebut dilakukan di kawasan aliran sungai gunung Muria desa Colo Kudus Jawa Tengah. Waktu penelitian ini dilakukan pada bulan Agustus 2018 dan Januari 2019. Teknik pengumpulan data dari penelitian ini menggunakan metode jelajah (visual day flying) (Virgiawan dkk., 2017). Teknik analisis data penelitian ini menggunakan analisis kuantitatif deskriptif. Analisis kuantitatif dilakukan untuk menghitung indeks keanekaragaman, indeks kemerataan, indeks dominansi, dan FBI (Family Biotic Indeks), sedangkan analisis deskriptif digunakan untuk mendeskripsikan jenis-jenis capung Anisoptera yang ditemukan pada saat penelitian.

\section{HASIL DAN PEMBAHASAN}

\section{A. Data Sampling Capung Anisoptera}

Hasil dari penelitian ini yaitu ditemukan 68 individu dalam lima spesies capung di antaranya Orthetrum chrysis (Jantan), Orthetrum pruinosum (Jantan), Orthetrum 
glaucum (Jantan \& Betina), Orthetrum sabina (Jantan), dan Trithermis festiva (Jantan). Kelima spesies capung tersebut terbagi menjadi dua genus yaitu Orthetrum dan Trithermis, dan masuk ke dalam satu famili yaitu Libellulidae.

Gambar spesies capung yang ditemukan pada saat penelitian sebagai berikut:

1. Spesies 1

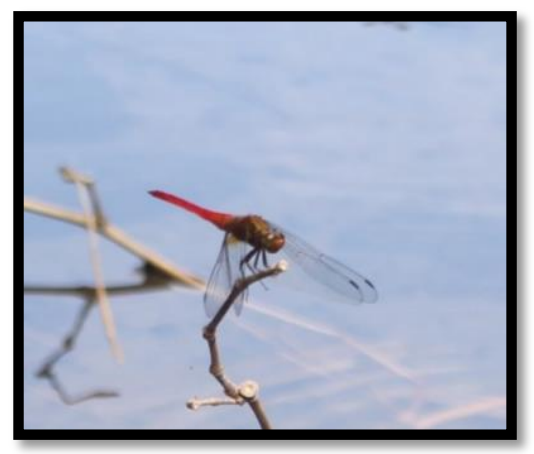

Gambar 1. Orthetrum chrysis (Jantan)

2. Spesies 2

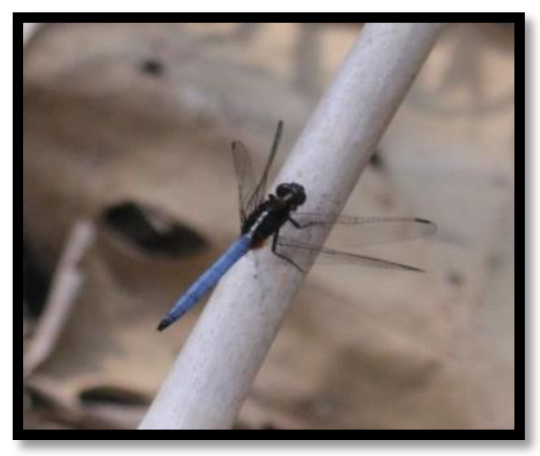

Gambar 2. Orthetrum glaucum (Jantan)

3. Spesies 3

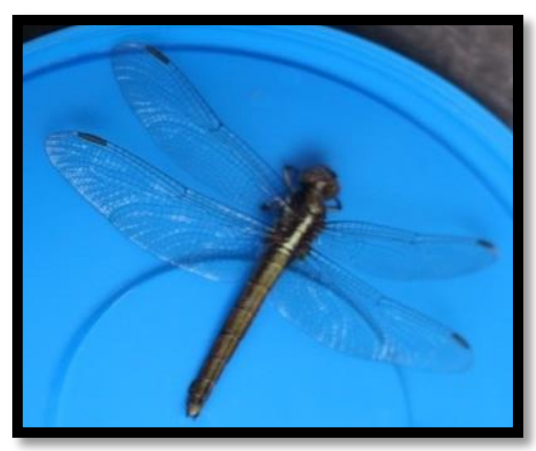

Gambar 3. Orthetrum glaucum (Betina) 
4. Spesies 4

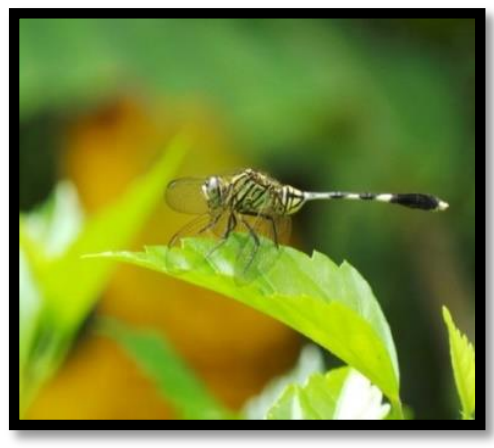

Gambar 4. Orthetrum sabina (Jantan)

5. Spesies 5

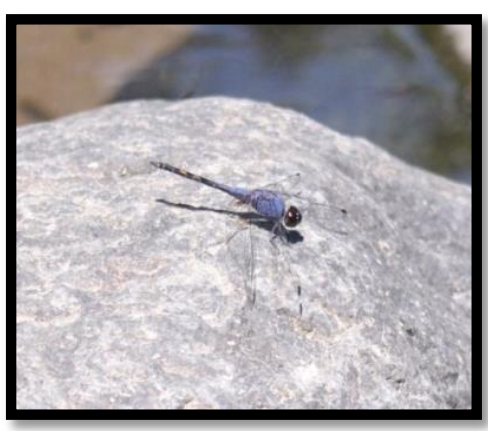

Gambar 5. Trithermis festiva (Jantan)

B. Indeks Keanekaragaman, Indeks Kemerataan, Indeks Dominansi, dan FBI (Family Biotic Indeks) Capung Anisoptera

1. Diagram 1

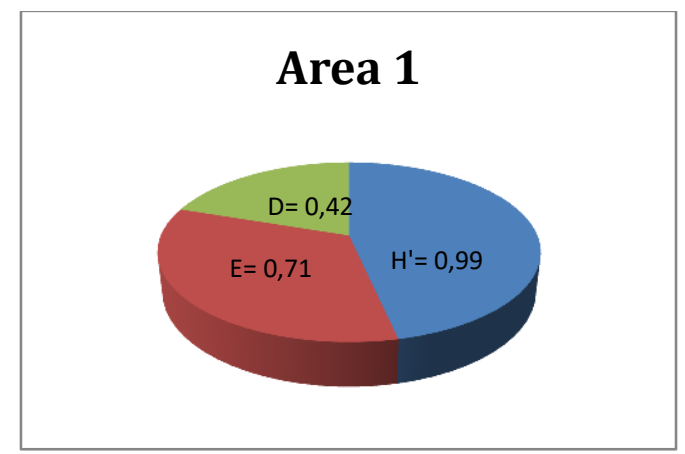

Gambar 5. Diagram Indeks Keanekaragaman, indeks kemerataan dan indeks dominansi area 1 
2. Diagram 2

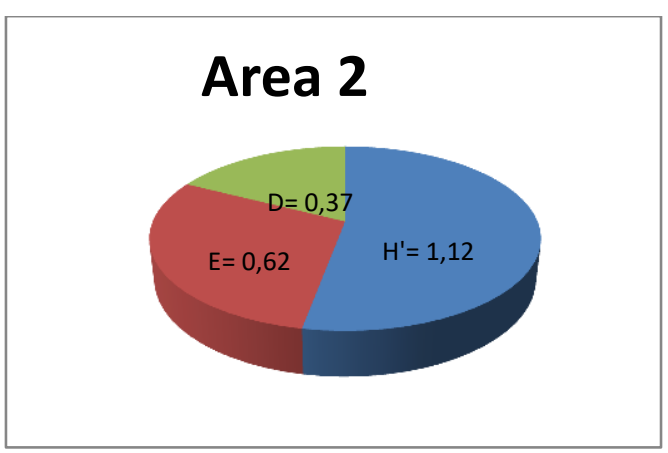

Gambar 6. Diagram Indeks Keanekaragaman, indeks kemerataan dan indeks dominansi area 2

3. Diagram 3

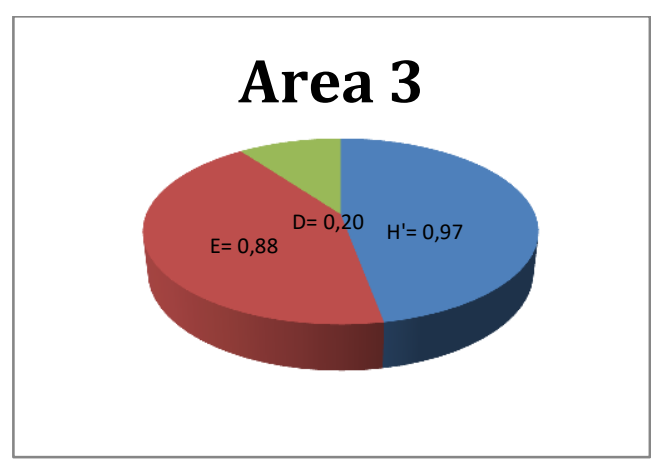

Gambar 7. Diagram Indeks Keanekaragaman, indeks kemerataan dan indeks dominansi area 3

Kategori penilaian indeks keanekaragaman indeks capung anisoptera ketiga area penelitian dapat dilihat pada Tabel 1. Kategori penilaian indeks keseragaman/kemerataan Capung Anisoptera ketiga area penelitian dapat dilihat pada Tabel 2. Kategori penilaian indeks dominansi Capung Anisoptera ketiga area penelitian dapat dilihat pada Tabel 3. Indeks FBI (Family Biotic Indeks) pada ketiga area penelitian dapat dilihat pada Tabel 4

Tabel 1. Kategori Penilaian Indeks Keanekaragaman Capung Anisoptera

\begin{tabular}{cccc}
\hline No & Area & Nilai Indeks Keanekaragaman $\left(\mathrm{H}^{\prime}\right)$ & Kategori \\
\hline 1. & I & 0,99 & Rendah \\
\hline 2. & II & 1,12 & Sedang \\
\hline 3. & III & 0,97 & Rendah \\
\hline
\end{tabular}

Tabel 2. Kategori Penilaian Indeks Keseragaman/Kemerataan Capung Anisoptera Ketiga Area Penelitian

\begin{tabular}{cccc}
\hline No & Area & Nilai Indeks Kemerataan (E) & Kategori \\
\hline 1. & I & 0,71 & Cukup merata \\
\hline 2. & II & 0,62 & Cukup merata \\
\hline 3. & III & 0,88 & Hampir merata \\
\hline
\end{tabular}


Tabel 3. Kategori Penilaian Indeks Dominansi Capung Anisoptera Ketiga Area Penelitian

\begin{tabular}{cccc}
\hline No & Stasiun & Nilai Indeks Dominansi (D) & Kategori \\
\hline 1. & I & 0,42 & Dominansi sedang \\
\hline 2. & II & 0,37 & Dominansi sedang \\
\hline 3. & III & 0,20 & Dominansi rendah \\
\hline
\end{tabular}

Tabel 4. Indeks FBI (Family Biotic Indeks) pada Ketiga Area Penelitian

\begin{tabular}{lclc}
\hline \multicolumn{1}{c}{ Famili } & Jumlah Individu (xi) & $\begin{array}{c}\text { Nilai } \\
\text { Toleransi (ti) }\end{array}$ & xi.ti \\
\hline Libellulidae & 65 & 2 & 130 \\
\hline Jumlah & 65 & & \\
\hline \multicolumn{4}{c}{ FBI $130 / 65=2$} \\
\hline
\end{tabular}

Indeks keaneakaragaman capung Anisoptera dari masing-masing area penelitian dianalisis menggunakan indeks keanekaragaman Shannon-Wiener. Hasil dari perhitungan indeks keanekaragaman pada masing-masing area diantaranya area $1(0,99)$ artinya area 1 memiliki keanekaragaman capung Anisoptera kategori rendah, area $2(1,12)$ artinya area 2 memiliki keanekaragaman capung Anisoptera kategori sedang, area $3(0,97)$ artinya area 3 memiliki keanekaragaman capung Anisoptera kategori rendah. Analisis indeks keanekaragaman (H') bertujuan untuk mengukur tingkat keteraturan dan ketidakteraturan dalam suatu sistem (Fachrul, 2007). Dari ketiga area tersebut yang memiliki indeks keanekaragaman paling tinggi yaitu area 2 sebesar 1,28, artinya area 2 tersebut memiliki ekosistem yang teratur, karena dengan adanya keanekaragaman jenis capung Anisoptera yang tinggi dapat menyeimbangkan ekosistem pada lokasi tersebut, mengingat bahwa capung memiliki kedudukan sebagai konsumen tingkat II pada tingkatan trofik dalam rantai makanan. Area yang memiliki indeks keanekaragaman paling rendah yaitu area 3 sebesar 0,974315, artinya area 3 tersebut memiliki ekosistem yang tidak teratur, karena dengan keanekaragaman jenis capung yang rendah kegiatan ekosistem pada lokasi tersebut terganggu, sehingga ekositem pada lokasi tersebut tidak seimbang.

Indeks kemerataan/keseragaman capung Anisoptera pada masing-masing area penelitian dianalisis menggunakan indeks kemerataan Simpson. Hasil perhitungan indeks kemerataan dari masing-masing penelitian diantaranya yaitu area $(0,71)$ artinya 
kemerataan capung Anisoptera pada area 1 termasuk dalam kategri cukup merata, area 2 $(0,62)$ artinya kemerataan capung Anisoptera pada area 2 termasuk dalam kategori cukup merata, area $3(0,88)$ artinya kemerataan capung Anisoptera pada area 3 termasuk dalam kategri hampir merata. Kemerataan merupakan pembagian individu yang merata diantara jenis (Virgiawan dkk., 2015). Menurut pengertian diatas dapat diartikan bahwa area 3 memiliki sumber daya alam seperti tanaman dan serangga lain yang keberadaannnya merata pada habitat area 3 tersebut sehingga dapat mendukung kehidupan capung Anisoptera. Keberadaan tumbuhan kopi, rumput-rumputan, angganganggang dan kecebong yang merata sangat mempengaruhi indeks kemerataan capung Anisoptera pada area 3.

Hasil perhitungan indeks dominansi capung Anisoptera pada masing-masing area penelitian diantaranya area $1(0,42)$ artinya dominansi capung Anisoptera pada area 1 masuk dalam kategori dominansi sedang, area $2(0,37)$ artinya dominansi capung Anisoptera pada area 2 masuk dalam kategori dominansi sedang, area $3(0,20)$ artinya dominansi capung Anisoptera pada area 3 masuk dalam kategori dominansi rendah. Adanya dominansi jenis tersebut menunjukkan bahwa sebaran jenis capung Anisoptera kurang merata. Kesesuaian habitat merupakan salah satu faktor terjadinya dominansi capung pada suatu lokasi. Trithemis festiva dijumpai sekitar perairan, alian sungai tepi hutan atau perkebunan serta di timbunan sampah organik dan seresah yang mulai mengering di sekitar perumahan atau kebun (Setyawati dkk., 2015).

Indeks FBI menunjukkan bahwa ketiga area tersebut memiliki nilai FBI sebesar 2 artinya dari jumlah famili capung Anisoptera yang ditemukan pada ketiga area penelitian menunjukkan bahwa kualitas air pada ketiga area penelitian tersebut tergolong paling baik atau tidak tercemar bahan organik. karena indeks FBI dapat digunakan untuk mendeteksi kualitas air yang tercemar dengan bahan organik. Makroinvertebrata yang hidup di dalam perairan sangat membutuhkan habitat yang sehat. FBI digunakan untuk mempercepat kerja biomonitoring karena hanya mengidentifikasi sampai pada tingkat famili dan penggunaan FBI tepat untuk perairan yang tercemar bahan organik, penggunaan FBI pada penelitian ini sangat cocok karena hasil analisis fisiko-kimia menunjukkan angka BOD tinggi yang mengindikasikan bahwa adanya bahan organik yang mencemari. Menurut teori disebutkan bahwa semakin tinggi nilai FBI maka semakin tinggi pencemaran bahan organik dan sebaliknya semakin rendah nilai FBI maka semakin rendah pula tingkat pencemaran bahan organik (Wahyudi, 2016). 


\section{Perbandingan Kualitas Air pada Tiga Area Penelitian yang Berbeda terhadap Keanekaragaman Capung Anisoptera}

Hasil dari perbandingan kualitas air pada ketiga area penelitian terhadap keanekaragaman capung Anisoptera menunjukkan bahwa area 1 memiliki kualitas air bersih baik dari pengukuran menggunakan parameter fisika maupun parameter kimia, akan tetapi area 1 memiliki keanearagaman jenis capung Anisoptera rendah, area 2 memiliki kualitas air bersih berdasarkan pengukuran parameter fisika, apabila berdasarkan pengukuran parameter kimia area 2 tercemar logam berat berupa timbal $(\mathrm{Pb})$, akan tetapi area 2 memiliki keanekaragaman jenis capung Anisoptera sedang, area 3 memiliki kualitas air bersih baik berdasaran pengukuran parameter fisika maupun parameter kimia, akan tetapi memiliki keanekaragaman jenis capung Anisoptera rendah.

\section{SIMPULAN}

Hasil analisis indeks keanekaragaman bahwa area $1(0,99)$ dan area $3(0,97)$ tergolong rendah, sedangkan area $2(1,12)$ tergolong sedang. Analisis indeks kemerataan menunjukkan bahwa area $1(0,71)$ dan area $2(0,62)$ cukup merata, sedangkan area 3 $(0,88)$ hampir merata. Hasil analisis indeks dominansi menunjukkan bahwa area $1(0,42)$ dan area $2(0,37)$ tergolong sedang, sedangkan area $3(0,20)$ rendah. Hasil analisis FBI (Family Biotic Indeks) menunjukkan bahwa ketiga area tersebut memiliki kualitas air yang tercemar. Perbandingan kualitas air pada ketiga area terhadap keanekaragaman jenis capung Anisoptera yaitu area 1 dan area 3 memiliki kualitas air bersih akan tetapi memiliki keanekaragaman jenis capung Anisoptera rendah, sedangkan untuk area 2 memiliki kualitas air tercemar akan tetapi memiliki keanekaragaman jenis capung Anisoptera sedang.

\section{DAFTAR PUSTAKA}

Baskoro, K, dkk. (2018). Odonata Semarang Raya Atlas Biodiverstas di Kawasan Semarang. Semarang: Departemen Biologi Fakultas Sains Dan Matematiak Universitas Diponegoro.

Fachrul, M F. (2007). Metode Sampling Bioekologi. Jakarta: PT Bumi Aksara.

Hanum, S O, dkk. (2013). Jenis-jenis Capung (Odonata) di Kawasan Taman Satwa Kandi Kota Sawahlunto, Sumatera Barat. J.Bio. UA. 2(1): 71-76. 
Herpina, Rima, Ade, F Y,. Afrianti E. (2014). Jenis-Jenis Capung (Odonata:Anisoptera) di Komplek Perkantoran Pemerintahan Daerah (PEMDA) Kabupaten Rokan Hulu. Program Studi Pendidikan Biologi. Fakultas Keguruan dan Ilmu Pendidikan Universitas Pasir Pengaraian.

Mushoffa, Ahmad Nazih. (2017). Keanekaragaman Capung di Sungai Winongo dan Pengembangannya Sebagai Modul Biologi Bermuatan Pendidikan Konservasi untuk Siswa SMA/MA Kelas X. Skripsi. Yogyakarta: Universitas Islam Negeri Sunan Kalijaga Yogyakarta.

Raco, J.R. (2010). Metode Penelitian Kualitatif Jenis, Karakter dan Keunggulan. Jakarta: Grasindo.

Rizal, Samsul, Mochammad Hadi. (2015). Inventarisasi Jenis Capung (Odonata) pada Areal Persawahan di Desa Pundenarum Kecamatan Karangawen Kabupaten Demak. Bioma. 17(1):16-20.

Setyawati, S M. (2015). Studi Biodiversitas Capung (Odonata) Tingkat Jenis dan Peranan Ekologisnya di Area Hutan Lindung Gunung Prau Jawa Tengah. Semarang: UIN Walisongo Semarang.

Susanti, Pranatasari Dyah dan Rahardyan, Nugroho Adi. (2017). Makroinvertebrata sebagai Bioindikator Pengamatan Kualitas Air. Prosiding Seminar Nasional Geografi UMS. Surakarta 2017.

Virgiawan, Candra, Iin Hindun, Sukarsono. (2015). Studi Keanekaragaman Capung (Odonata) Sebagai Bioindikator Kualitas Air Sungai Brantas Batu-Malang dan Sumber Belajar Biologi. Pendidikan Biologi Indonesia. 1(2): 188-196.

Wahyudi, G.I, dkk. (2016). Evaluasi Kualitas Air Berdasarkan Struktur Komunitas Makroinvertebrata Bentos dan Persepsi Masyarakat tentang Pengelolaan Perairan di Wilayah Rawa Bayu, Songgon, Banyuwangi. Biotropika. 4(2): 43-48. 